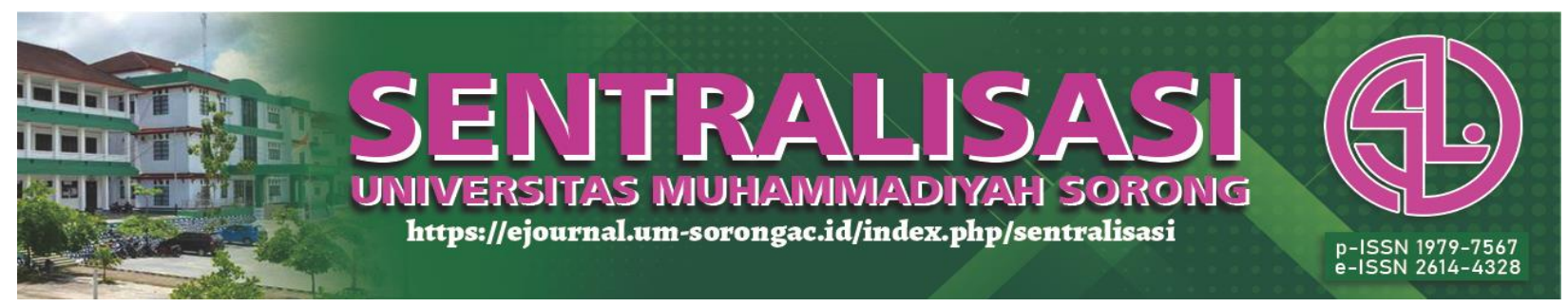

\title{
Wife's Accountability in Islamic Household Accounting
}

\author{
Diah Ayu Gustiningsih ${ }^{1}$, Mediaty ${ }^{2}$, Alimuddin $^{3}$, Andi Kusumawati ${ }^{4}$ \\ ${ }^{1}$ Prodi Akuntansi, STIE Tri Dharma Nusantara, Indonesia \\ ${ }^{2,3,4}$ Fakultas Ekonomi dan Bisnis, Universitas Hasanuddin, Indonesia
}
Email : *diahdani57@gmail.com
* corresponding author

\section{direvisi: 30/12/2021 dipublikasikan: 08/01/2022}

\begin{abstract}
Abstrak. Penelitian ini dilakukan guna menemukan bentuk dari pertanggungjawaban seorang istri dalam akuntansi rumah tangga Islam, dengan pendekatan fenomenologi transcendental. Tehnik analisis fenomenologi transcendental meliputi 5 tahapan yaitu: noema, noesis, epoche, intentional analysis dan eidetic reduction. Hasil penelitian menunjukkan bahwa pertanggungjawaban yang dilakukan Istri dalam rumah tangga Islam yang dilakukan dalam rumah tangganya, adalah pertanggungjawaban dengan tujuan menjaga harga diri dan menjaga citra diri terhadap suami, atas pengeluaran-pengeluaran yang dilakukan, dimana ada 6 pertanggungjawaban yaitu: pendapatan, nafkah, ZIS, konsumsi, investasi, dan tabungan ke dalam 4 pusat pertanggungjawaban yaitu: pusat pendapatan, pusat biaya, pusat investasi dan pusat kekayaan
\end{abstract}

Kata kunci: Pertanggungjawaban, istri, akuntansi, rumah tangga Islam

Abstract. This study was conducted to find the form of a wife's responsibility in Islamic household accounting, with a transcendental phenomenological approach. Transcendental phenomenological analysis techniques include 5 stages, namely: noema, noesis, epoche, intentional analysis and eidetic reduction. The results of the study indicate that the responsibility carried out by the wife in an Islamic household carried out in her household is accountability with the aim of maintaining self-esteem and maintaining self-image of her husband, for the expenses made, where there are 6 responsibilities, namely: income, maintenance, ZIS , consumption, investment, and saving into 4 responsibility centers, namely: revenue center, cost center, investment center and wealth center.

Keywords: Accountability, wife, accounting, Islamic household

\section{Introduction}

Welfare in Islamic households, is able to provide welfare in other households through zakat, infaq and alms activities. Welfare in Islamic households can also be achieved with the help of accounting practices in the household itself. In several studies the holder of an important role in 


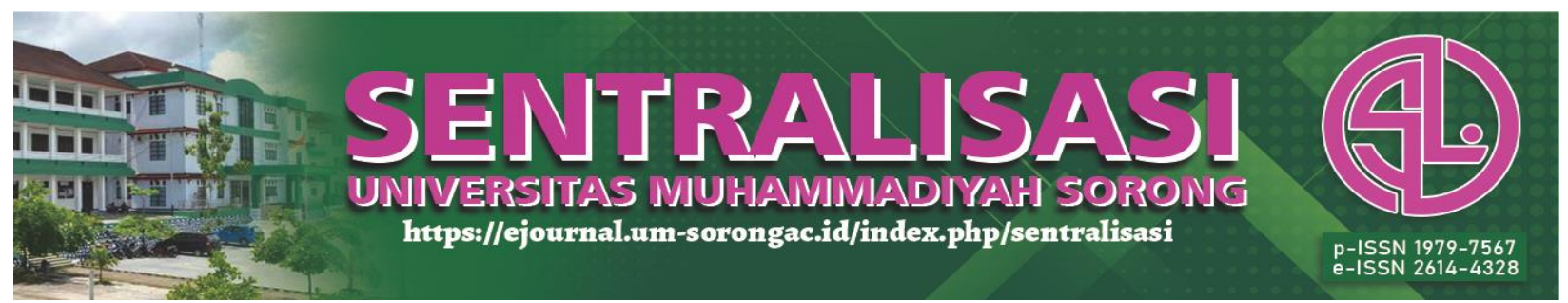

household accounting practices is held by the wife, (Komori, 2012) mentions that even through accounting, a wife and mother are able to express their maternal feelings, in his research it is shown how accounting information understood by a wife in her household can help her husband to maintain the continuity of his household while maintaining the quality of his household life. Northcott \& Doolin (2015) also found that well-executed accounting in a household is able to prevent households from debt problems which can reduce welfare in the household.

Several studies related to accounting in the household sphere have attracted several researchers, who consider that the macro quality of a society lies in the micro units of its household. In the early 20th century Piorkowsky (2000) researched the implementation of household accounting in Germany and the results showed that less than 30 percent of German households keep accounting records regularly. These findings were used to design "Das Neue Haushalysbuch, an accounting book about households in Germany. Carnegie \& Walker (2007) also conducted a study of accounting practiced on household activities in Australia. Turning to Japan, (Komori, 2012) also conducted accounting research in the household, with a focus on women (about the maternal nature of Japanese women, and it was found that accounting practices in Japanese households are in accordance with traditional accounting practices.

Furthermore, (Ramlugun et al., 2016) research related to household accounting was also carried out in the Mauritius area, the results were that the application of household accounting there was used to evaluate debt and taxes in the household. Meanwhile Rant et al (2017) conducted research on household accounting in Slovenia with subsidized corporate households as the object, while in Indonesia itself, research on household accounting has also been carried out by Mulyani \& Budiman (2018), Setiowati (2016), Espa (2016), Raharjo \& Kamayanti (2015), Yulianti (2015) and Manurung and Sinton (2013), it's just that from the various household accounting studies carried out, no one has examined specifically for households in managing their consumption patterns and their responsibilities.

The quality of life of the household that is maintained will increase the welfare of the household so that it can indirectly contribute to improving the welfare of other households 


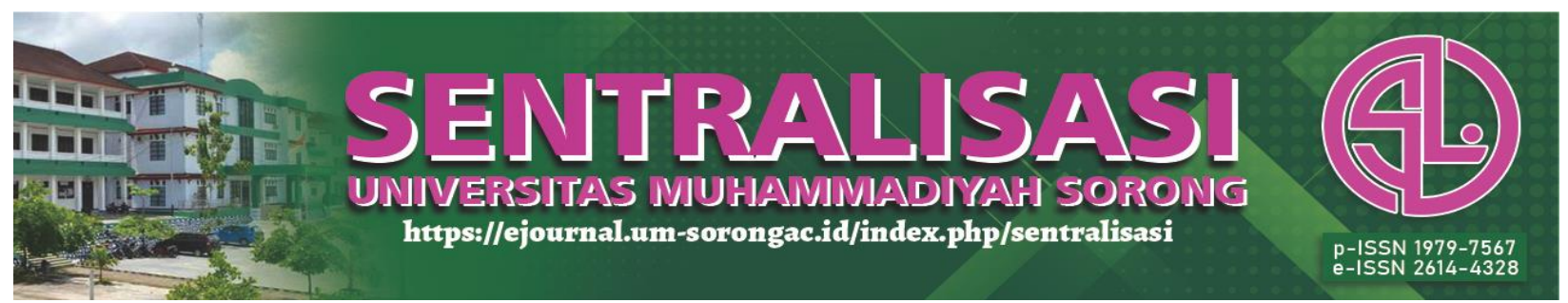

(Gustiningsih et al., 2021). A good consumption pattern also contributes to maintaining the quality of the household, in terms of economic resilience that can affect the quality of education and health in the household, of course, consumption patterns also play a role in determining the consumption pattern chosen by each household. There is a stake in the decision-making actors in the household. A wife, is an important actor in this, Mediaty et al (2021) explained that women in the household are tasked with recording every economic activity in their household and then providing this information even in the description of records to be considered by the household when needed.

In addition, in some accounting practices that exist in the household, a wife also acts as the manager of household finances (Tamanni \& Mukhlisin, 2018). The financial cycle in the household that is portrayed is that it is common for a husband to hand over his income to his wife to manage for household needs, for wives who do not work and the source of income is only from their husbands, while for the form of every transaction in the household it is possible to be realized in the recording of the household. Puspitaningtyas (2013) even explains if a wife is able to carry out management in her household finances starting from planning, budgeting, managing, finding sources of funds, storage to evaluation. Manurung \& Sinton (2013) have found a form of conventional household accounting. Furthermore, what about the form of accounting practice for Islamic households where these households have a different basis to run.

Islamic households are formed to carry out worship to Allah SAW (Nurhadi, 2018), thus has a basis of accountability not only vertically but also horizontally. Thus the responsibility centers that exist in Islamic households will also be different from conventional households. The responsibility center is a fragmented part of an organization, if so how is this responsibility center also fragmented in an Islamic household, when the household is considered to be one of the smallest organizations in the existing society. Researchers want to find patterns of accountability that exist in Islamic households that are formed with a phenomenological approach. It is hoped that with this research, the pattern of accountability represented by the responsibility centers of a wife in an Islamic household is able to carry out the objectives of the establishment of a household. Where responsibility centers can be used for control systems, including controlling consumption 


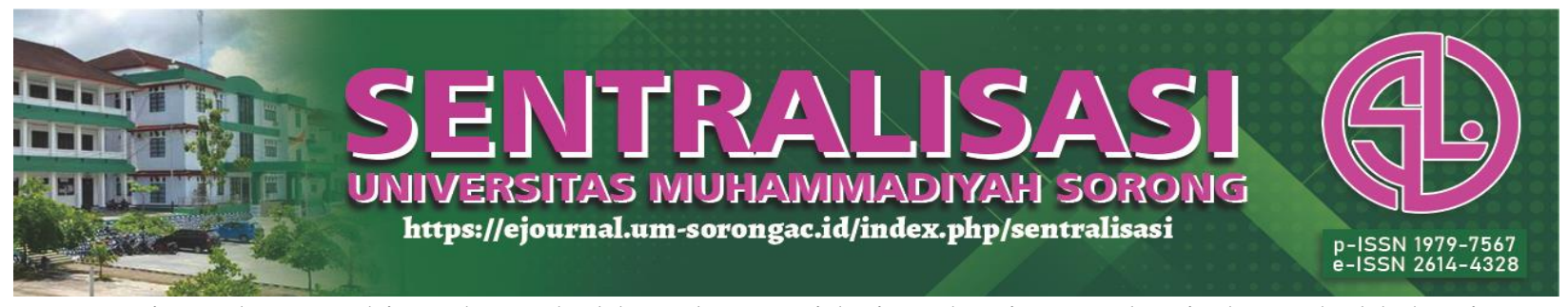

patterns in order to achieve household goals, considering that in an Islamic household that is run with the guidance of the Qur'an, hadith, ijma ulama and giyas is a consumption pattern that contains maslahah in it (Luthfi, 2019).

\section{Research Methodology}

This research is a qualitative research using a transcendental phenomenology approach. Transcendental phenomenology launched by Edmund Husserl focuses on a study of consciousness. This methodological approach is used to reveal the meaning of the responsibility of a wife in an Islamic household. The analysis technique is carried out through the stages of analysis: starting with the identification of noema, namely analyzing testural, the results of the analysis the researcher will put bracketing if you get another under the texture to get a deeper level of meaning or called noesis, the next stage is the researcher will carry out further understanding how noesis is able to form noema through intentional analysis, the final stage namely by doing eidetic reduction, namely the researcher reduces the results of all stages to get the idea that underlies all pure awareness of the informants (Kamayanti, 2021). The main data of this study were collected from interviews, and observations of the activities, behaviors, and words of the informants. The informant in this study is a wife in an Islamic household who works as an accounting lecturer. The informants were chosen because they met the criteria for understanding accounting and understanding responsibilities in Islamic households. As well as a supporting informant, an expert in Islamic law who is also an expert in Islamic economics.

\section{Discussion}

Basically, Islamic households must run according to Islamic sharia, therefore, Islamic households also have obligations inherent in every household. Responsibilities that require accountability. The household consists of 2 actors, each of whom has a role, especially in the development of the era which is starting to become natural when wives also work, so they have income. Both husband and wife basically have their respective rights and obligations. So that good 


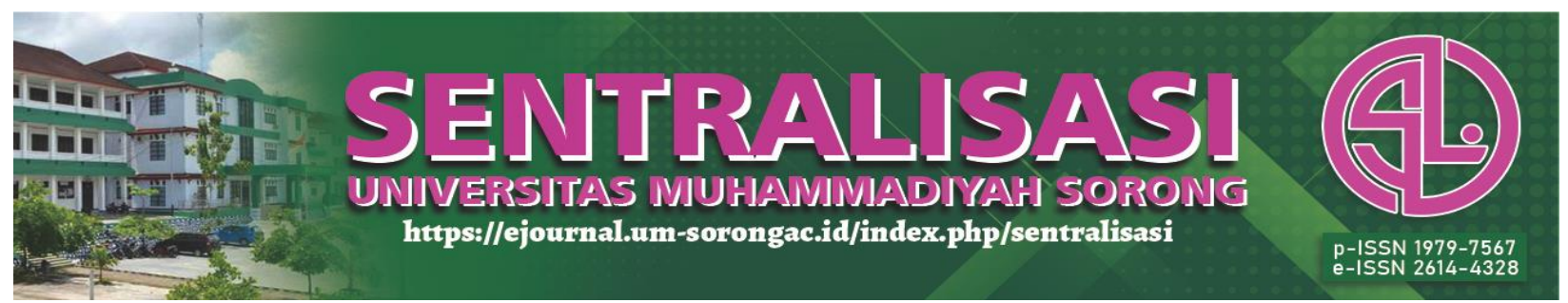

harmonization is needed so that the household runs in harmony and achieve the main goals, namely sakinah, mawaddah and warrahmah (Kompilasi Hukum Islam, 2001)

The existence of income and financial management in the household, of course there is a pattern for managing, as well as appointments or mandates in managing household finances. Inflows originating from the income of each actor will lead to household income, which will later be distributed in a pattern, which is influenced by the characteristics of the manager. Thus the manager will carry out accountability with good accountability. Good accountability will have an impact on the trust of the trustee. The results of interviews with informants found 4 responsibility centers that occur from the economic activities of a wife in an Islamic household, namely: income responsibility center, cost responsibility center, investment responsibility center, and wealth responsibility center.

\section{Wife's Income Responsibility Center}

The right of a wife from her husband is to earn a living for her personal needs and household management needs. In line with the development of time, more and more wives have careers in their fields of work, so that in the daily activities of a wife there is also a cash turnover from economic transaction activities. The results of the researcher's interviews with informants are all wives who work and earn a steady income when married are entitled to ask for a dowry and earn a living from their husband. The informant's opinion is this noema, where noesis in this case is the obligation of a husband to give a dowry at the beginning of marriage, is one of the conditions for marriage in Islam, as well as the obligation to provide a living in an Islamic household.

This means that in the responsibility center, the wife's income is derived from income earned at work, income given by her husband through a living, and income received during marriage in the form of a dowry. The cash flow which initially only came from managing a living when the wife was not working, changed to the income earned by the wife while working. The income of a wife while working is not fully demanded in the household, thus it is the wife's full ownership right. A gift from a husband to his wife is also full ownership. Income from a working 


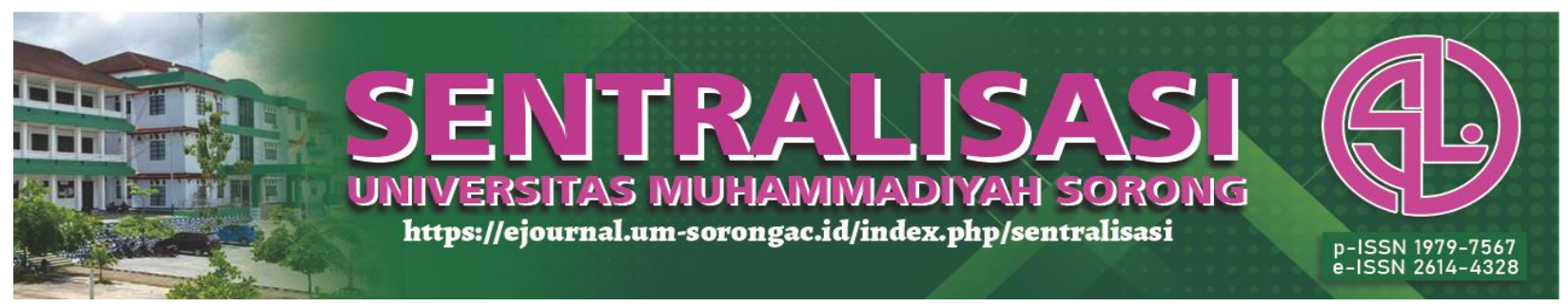

wife, dowry and maintenance are the full ownership of the wife. Other existing ownership is related to the inheritance obtained by the wife if any. Because not all wives have inheritance. Full ownership of this wife is a form of liberation of women from all forms of shackles, and Islam restores women's rights.

\section{Wife Cost Responsibility Center}

In the household accounting process for the wife, what happens is a reflection of the management of the form of living into household economic transaction activities, namely for household operational needs, or in other words to meet primary, secondary and tertiary needs in the household. These needs in the economy are also explained in the form of household consumption. The informant said in the interview that the source of income from the husband will be used for all household operational activities, while the opinion of the informant from work is that he has full rights and his use is only for the purposes of the informant. The informant's statement is an explicit awareness (noema), the next deep reason (noesis) is that the wife's income is not intended to take over the obligation to provide maintenance in the household, which is still held by the husband, that is what Islam teaches. At this point, the informant's understanding of "I" is the distribution of income from the husband to finance household needs, along with the wife's needs, while fulfilling household needs including the wife's personal needs is the husband's obligation to fulfill it, while the application of this is clearly in accordance with sharia.

\section{Wife Investment Responsibility Center}

The household financial cycle where during the current period in the household there is a decision to invest, the informant explains explicitly that there is no desire to invest from the results of his work, so far the investments made in his household use the flow of funds from his husband, if any. more, the informant will save and buy jewelry from his sweat, but for investment in houses and cars the income comes from the husband's income which he manages. The noesis that is formed is the wife's lack of concern for her needs, including in terms of investment, because again there is a husband who will provide for her. This means that "I" as a wife is able to ensure that 


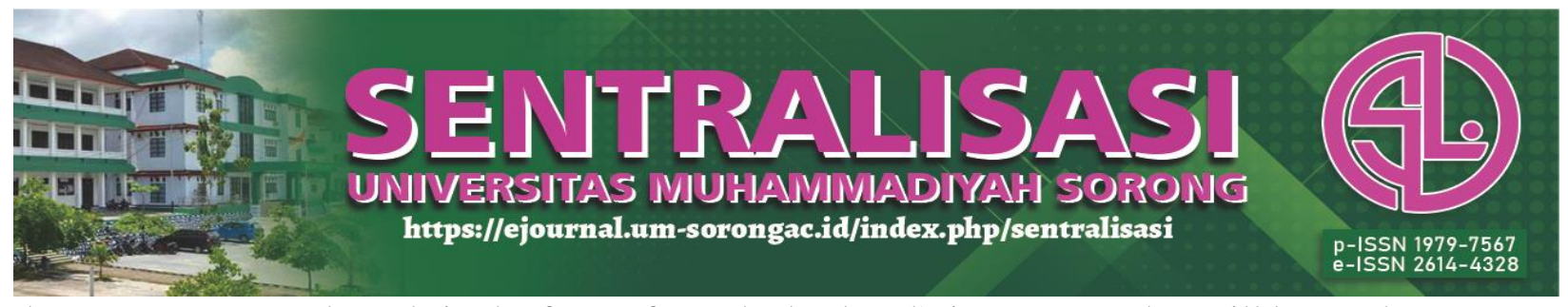

there are guaranteed needs in the future from the husband's investment that will be used to support me.

\section{Wife's Wealth Responsibility Center}

Islamic households cannot be separated from zakat, both income zakat and zakat mal for those who have reached the nisab and haul. Informants feel that zakat is the obligation of every individual in the household, zakat income for those who have income and zakat mal for those who have assets have reached the nisab and haul. This opinion of the informant is a form of explicit awareness (noema), due to his experience during running a household according to sharia which was taught by his parents, which in turn formed a deeper awareness (noesis). At this point, the informant's understanding of "I" is that I distribute part of my income and wealth for zakat in accordance with the command to pay zakat, in Islam. I realized that as a wife in the household I had to make sure that my household and I paid zakat.

Farooq (2014) explained in Islam, those who have wealth are responsible for channeling their wealth to those in need, Islam does not recognize the management of wealth which is only selfish at the expense of other households, especially by neglecting the rights of the poor and orphans. Sustainable and equitable wealth management is not only compatible, but also facilitated by broad economic development in which the standard of living of an increasingly large proportion of the population is increasing. More importantly, Islam enforces the basic principle of everincreasing concentration of wealth which causes wealth to circulate among the few rich and places a certain burden on the rich to avoid an undesirable level of concentration of how the rich get richer and the poor get poorer. 


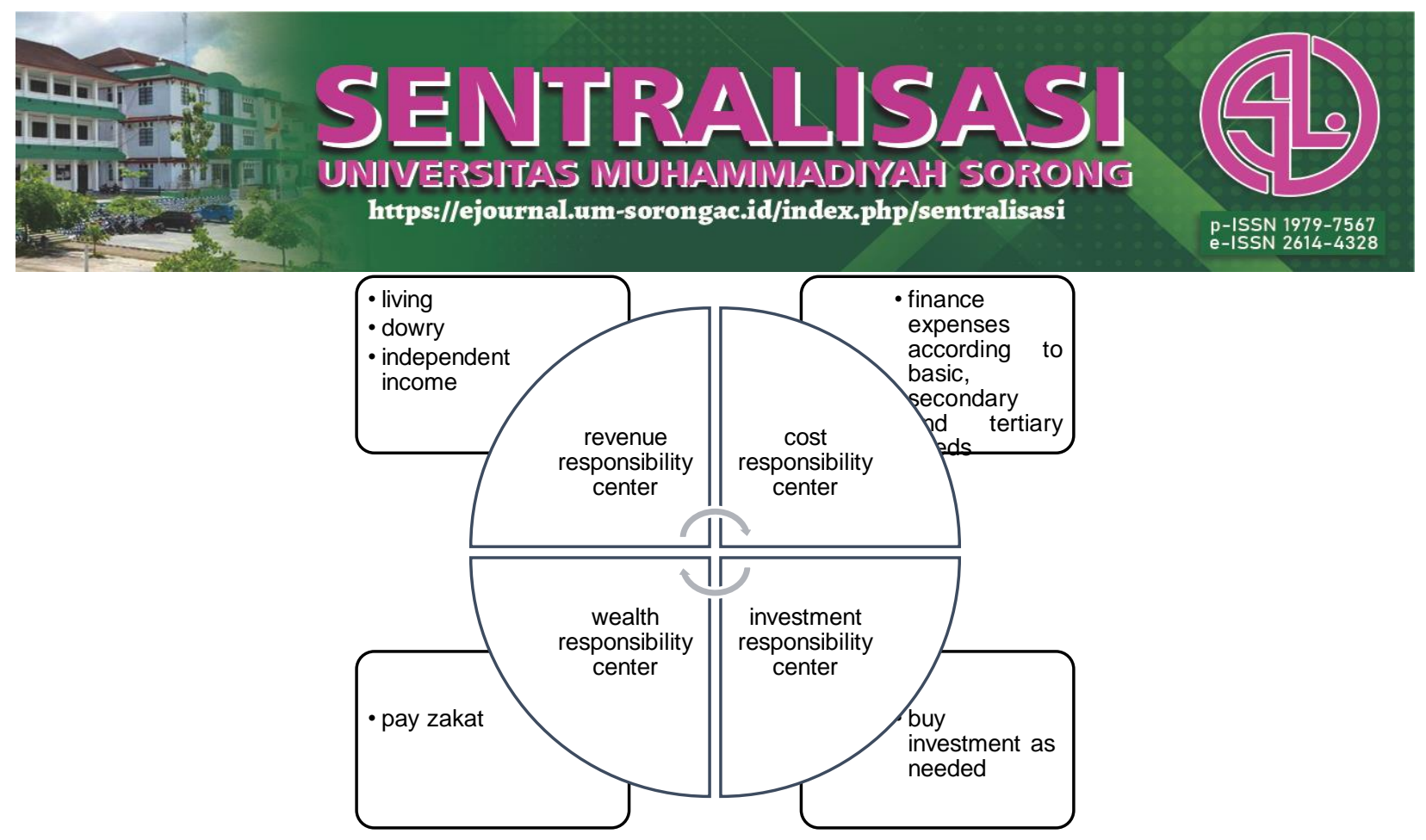

Source: researcher (2021)

Picture 1. Wives Accountability Centers in Islamic Households

The responsibility center that was established came from the informant, and the informant explained that he did this in accordance with his understanding of the holy verses of the Koran along with direct examples obtained from his parents. As guidelines in household financial management are based on An Nisa ayat 34:

"Men are the protectors and maintainers of women, because Allah has given the one more (strength) than the other, and because they support them from their means. Therefore the righteous women are devoutly obedient, and guard in (the husband's) absence what Allah would have them guard. As to those women on whose part ye fear disloyalty and ill-conduct, admonish them (first), (Next), refuse to share their beds, (And last) beat them (lightly); but if they return to obedience, seek not against them Means (of annoyance): For Allah is Most High, great (above you all)".

This verse emphasizes that the husband's position in the household is a leader who is obliged to provide protection for his family. In general, it is understood that the subordinates what is meant by the leader is a role model in a certain scope whose task is to determine the future of that scope. Leaders in accounting themselves, are usually described as decision makers in determining company policies. Similarly, in making decisions related to financial transactions that occur within the household itself. Financial transactions in an Islamic household will have different 


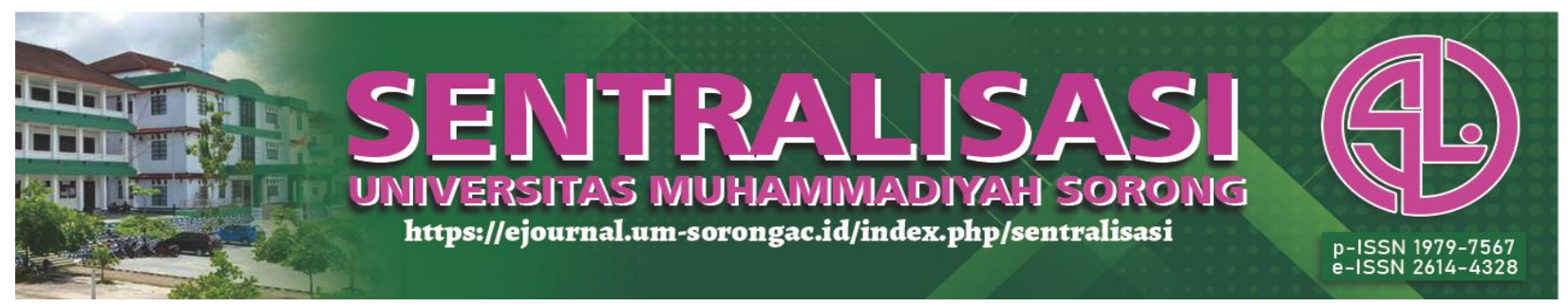

transaction processes according to the obligations and rights of the husband and wife themselves.

Islam emphasizes that there are transactions that are different from other conventional households.

The basic difference lies in the obligation of every husband to provide for his wife.

The results of interviews with informants found that accountability in the form of written accounting was only carried out when needed, namely when the husband questioned the distribution of income managed by the wife. Written accountability is not routinely carried out, the reason given by the informant, this is because the husband's trust in the informant is very strong, because the household has been run for more than 15 years and there are no problems. Accountability is more often carried out communicatively, through mental accounting, unstructured delivery, only providing information that is remembered, and only what the husband wants to know. Informants feel that the responsibility cannot be abandoned, by all wives towards their respective husbands. Her experience for more than 15 years, being a wife, trust exists because of accountability. At this stage the understanding of "I" by the informant is that I use responsibility to gain the trust of my husband, because I am aware that as a wife I must be trusted to manage finances.

\section{Conclusion}

A wife is an important actor in an Islamic household. Financial management that comes from the husband's living in the household becomes the duty of a wife to distribute it. Proper distribution in accordance with the sharia principles that he understands and makes the family more prosperous, is his duty. Thus the management has 4 responsibility centers, namely responsibility for income, responsibility for costs, accountability for investments and accountability for wealth. This accountability is one way to gain trust and a wife's way to show her self-respect in the ability to manage finances.

\section{Refferences}

Al Qur'an tafsir perkata. (2014). Lajnah Pentashihan Mushaf Al-Qur'an. 


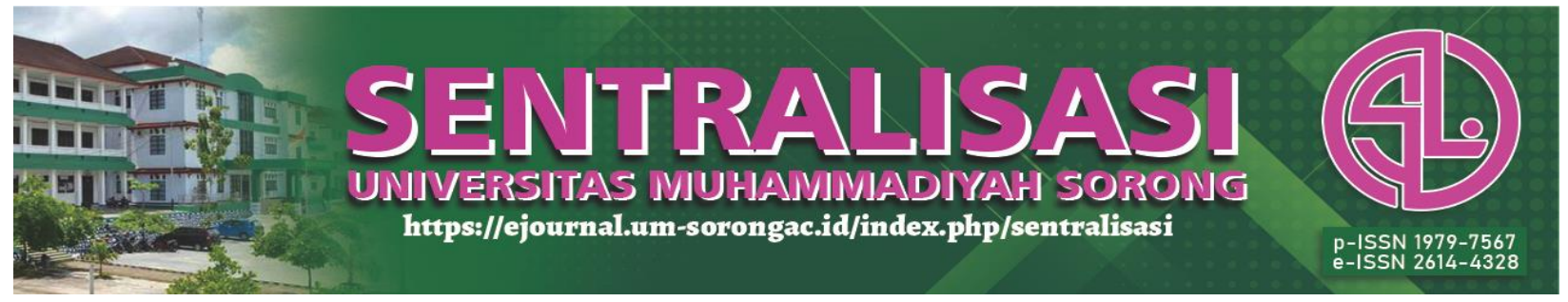

Carnegie, G. D., \& Walker, S. P. (2007). Household accounting in Australia: A microhistorical study. Accounting, Auditing and Accountability Journal, 20(2), 210-236.

https://doi.org/10.1108/09513570710741000

Espa, V. (2016). Rancangan Sistem Informasi Akuntansi Keluarga. Jurnal Audit Dan Akuntansi Fakultas Ekonomi Dan Bisnis Universitas Tanjungpura, 5(1), 19-48.

Farooq, M. O. (2014). Islamic Wealth Management and the Pursuit of Positive-Sum Solutions. Islamic Economic Studies, 22(2), 99-124. https://doi.org/10.12816/0008097

Gustiningsih, D. A., Mediaty, Alimuddin, \& Kusumawati, A. (2021). Problematics Accounting Practices for Islamic Households. Psychology and Education, 58, 386-392.

Komori, N. (2012). Visualizing the negative space: Making feminine accounting practices visible by reference to Japanese women's household accounting practices. Critical Perspectives on Accounting, 23(6), 451-467. https://doi.org/10.1016/j.cpa.2012.04.006

Kompilasi Hukum Islam. (2001). 22. file://C:/Users/LENOVO/Downloads/ERIA - Ley 27446 y-reglamento-del-SEIA1.pdf

Luthfi, M. (2019). Konsumsi Dalam Perspektif Ilmu Ekonomi Islam. Madani Syari'ah, 2, 65-78. Manurung, D. T. ., \& Sinton, J. (2013). Urgensi Peran Akuntansi Dalam Rumah Tangga. Jurnal Ilmiah Akuntansi Dan Humanika JINAH, 3(No.1), 892-911.

Mediaty, Gustiningsih, D. A., \& Kusumawati, A. (2021). The Role Of Women And Accounting In Islamic. 2(June), 17-22.

Mulyani, S., \& Budiman, N. A. (2018). Pentingnya Akuntansi Rumah Tangga Dalam Meningkatkan Hidup Islami. Equilibrium: Jurnal Ekonomi Syariah, 6(2), 206. https://doi.org/10.21043/equilibrium.v6i2.3707

Northcott, D., \& Doolin, B. (2015). Home accountants : Exploring their practices Accounting , Auditing \& Accountability Journal Article information : October 2000. https://doi.org/10.1108/09513570010338267

Nurhadi, N. (2018). Undang-Undang No. 1 Tahun 1974 Tentang Pernikahan (Perkawinan) di Tinjau dari Maqashid Syariah. UIR Law Review, 2(2), 414. https://doi.org/10.25299/uirlrev.2018.vol2(02).1841

Piorkowsky, M. (2000). Household accounting in Germany - Some statistical evidence and the 


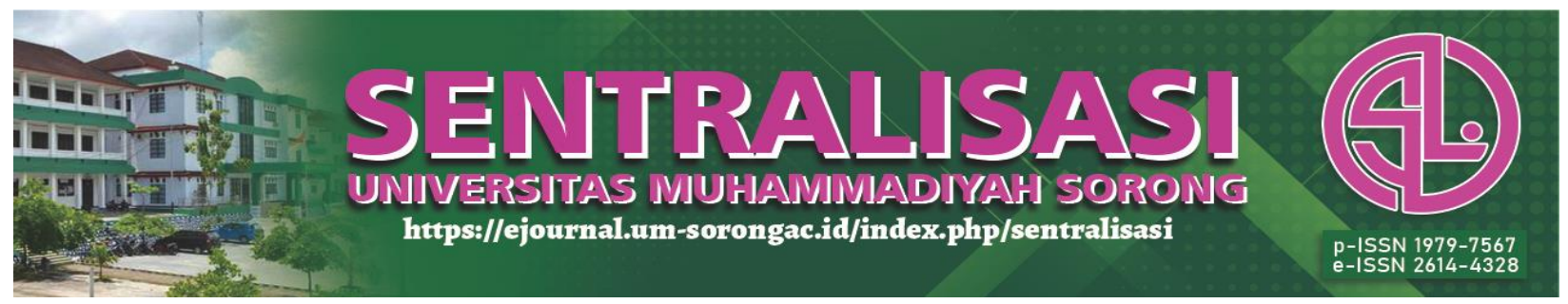

development of new systems. Accounting, Auditing \& Accountability Journal, 13, 518-534. https://doi.org/10.1108/09513570010338087

Raharjo, A. prima, \& Kamayanti, A. (2015). Household accounting values and implementation: an interpretive study. The Indonesia Journal of Accounting Research, 18(1), 74-96.

Ramlugun, V. G., Ramdhony, D., \& Poornima, B. (2016). An Evaluation of Household Accounting in Mauritius. International Journal of Accounting and Financial Reporting, 6(2), 62. https://doi.org/10.5296/ijafr.v6i2.9840

Rant, D., Horvat, R., Tominc, P., \& Korošec, B. (2017). Household Accounting - A Case of Subsidised Self-Employed Entrepreneurs in Slovenia. Naše Gospodarstvo/Our Economy, 63(2), 32-40. https://doi.org/10.1515/ngoe-2017-0010

Setiowati, N. E. (2016). Perempuan, Strategi Nafkah Dan Akuntansi Rumah Tangga. Perbankan Syariah Fakultas Syariah Dan Ekonomi Islam IAIN Syekh Nurjati Cirebon, 298-304.

Tamanni, L., \& Mukhlisin, M. (2018). Sakinah Finance. Tinta Medina.

Yulianti, M. (2015). Akuntansi dalam Rumah Tangga: Studi Fenomenologi pada Akuntan dan Non Akuntan. Skripsi Politeknik Negeri Padang, 11(2), 62-75. 